\title{
What is the share of population to the agro- industrial economy? A measure of demographic dividend in Indonesia
}

\author{
Wilson Rajagukguk ${ }^{1, *}$ \\ ${ }^{1}$ Universitas Kristen Indonesia, Faculty of Economics and Business, 13630 Jakarta, Indonesia
}

\begin{abstract}
This study aims to measure the share of population to economic growth, demographic dividend, in Indonesia. The analysis employed the Cobb-Douglas model. The data came from the Indonesia's National Account in 1970-2015, divided into two time spans (1970-1992 and 1993-2015). The dependent variable is the gross domestic product at current prices. The independent variables are investment, population, and employment opportunity. The demographic dividend is defined as the difference in the share of population between the first time span and second time span. It was found that the magnitude of demographic dividend through the whole population is $1.8874 \%$ and through the employment opportunity is $1.4557 \%$. The measure of demographic dividend in this study is a new measure of demographic dividend in Indonesia.
\end{abstract}

\section{Introduction}

Indonesia is the largest country in Southeast Asia. It is also an island nation with more than 300 ethnic groups. The economy of Indonesia experienced a good growth, in particular since the Asian financial crises in the 1990s. One of economic capital of Indonesia is its large population. Statistics Indonesia [1] reported that in 2017, the economic structure of Indonesia by expenditure was dominated by household consumption expenditure that is $56.13 \%$. This indicates that the large population of Indonesia has a positive impact on its economic structure.

Historically, the population of Indonesia is large. It increased from 60.7 million in 1930, to 97.1 million in 1961, to 119.2 million in 1971 and to 237,6 million in 2010 [2]. Although the number of population increases continuously, its growth declined from $2.33 \%$ per annum during 1971-1980 to $1.49 \%$ per annum during 2000-2010. This decline is mainly caused by the significant decline in fertility that has been attributed to the success of the national family planning program during 1970-2000, together with the improvement in women's education and participation in the labor force [3]. During the 1960s, on average an Indonesian woman would have almost six children at the end of their reproductive age [4]. This total fertility rate declined to around 2.5 children per woman during the $2010 \mathrm{~s}$.

*Corresponding author: wrajagukguk@yahoo.com 
Decline in fertility and mortality in Indonesia has resulted in a favorable population age structure where the number of young children age under 15 years is declining relative to the number of productive age population (15-64 years). This has resulted in the decline in the dependency ratio, the ratio between the number of dependent population (young children aged $0-14$ years and older population aged 65 years and above) and the number of productive age population (aged 15-64 years), from 86.8 dependent people per 100 productive age population in 1971 to 51.3 in 2010 [5]. It is projected that the dependency ratio will reach its lowest of 46.875 in 2029 [6].

Investment in both physical and human capital during this window of opportunity has resulted in demographic dividend of accelerated economic growth in some countries, such as Ireland, Japan, Singapore, South Korea and Taiwan, during the 1980s. Has Indonesia also experienced the demographic dividend? What is the measure and the magnitude?

This study aims to measure the share (output elasticity) of population and employment opportunity to the economic growth and the magnitude of the demographic dividend. In this study, the demographic dividend is defined as the increase in the share of population and employment opportunity to the economy.

The paper consists of five sections. The background and objectives of the study is presented in this section. In section 2, the literatures relevant to this study are reviewed. The data and methodology used in this study are discussed in Section 3. The results of empirical analysis are presented and discussed in section 4 . The paper is closed with conclusions and policy implications presented in section 5 .

\section{Literature review}

All countries in the world are classified in four groups in terms of development achievement in economic and human capital, i.e. demographic dynamics [7]. These groups are pre-demographic dividend, early-demographic dividend, late demographic dividend, and post-demographic dividend countries. Pre-demographic dividend countries are typically low-income countries, lagging in key human development indicators and with increasing percentage of productive age population and current fertility levels above four children per woman which results in rapid population growth. Early demographic dividend countries are typically lower-middle-income countries with the fertility transition. In these countries, fertility rates have fallen below four children per woman and the productive age share of the population is likely rising notably. Late demographic dividend countries are typically upper-middle-income countries where the percentage of productive age population is declining and fertility rates are typically above replacement levels of 2.1 children per woman, but fertility continues to decline. Post-demographic dividend countries are typically high-income countries where the productive age share of the population is declining and fertility has transitioned below replacement levels. With this classification, Indonesia is grouped into early demographic dividend country. It was argued that the window of opportunity to reap the demographic dividend in Indonesia has occurred since the 1970 s when fertility started declining $[8,9]$.

However, demographic dividend is not automatic. It is a joint impact of economic policies in a country. Factors such as health, education, trade policy, industrial policy, government administration, culture, geography, saving, and capital accumulation are other important factors for the demographic dividend [11]. There are four policy steps to reach the demographic dividend: initiating demographic change, improving people's health, investing in education, and implementing economic and governance policies. The first step toward a demographic dividend is a rapid fertility decline through investments in family planning, child survival and educating girls. Healthy children do better in school, and this success ultimately contributes to a higher-skilled labor force. Youth also have health needs 
to be addressed, and maintaining the health of adults is critical to economic productivity. Education systems must focus on ensuring that more young people complete school and giving youth the skills to adapt to the changing labor market. Economic and governance policies must foster job growth and investment in labor-intensive sectors, support the expansion of infrastructure, promote trade to ensure access to international markets, and create a secure environment and incentives for foreign direct investment.

The impacts of population on economic growth have been documented [11-13]. Simon argued that the main engine of world's development acceleration is the stock of people's knowledge [11]. He proposed that the ultimate resources of accelerated growth are the people, who are skilled, spirited, and hopeful, and who exercise their wills and imaginations for their welfare and the welfare of all people. Meanwhile, Jones modified Romer's model [12] and argued that economic growth rate is proportional to population size [13]. One thing continuously happens in Romer's model is while the population increases, the per capita economic growth rate also increases [14].

Measures of the impacts of change in population age structure on economic growth have been developed. Mason, using national transfer account based on life-cycle approach of consumption and production patterns, concluded that if capitalized optimally, the demographic dividend contributed between one and two percent point to economic growth during 1970-2000 in most of regions in the world [15]. Meanwhile, Maliki, based also on consumption and production patterns, found that the demographic dividend due to the declining percentage of young children contributed less than one percent to economic growth in Indonesia, while the demographic dividend due to the increasing number of older people gave higher contribution, around 1.8\% [16]. Further, in their study, Felipe and Adams found that the share of population to the world's economy, employing CobbDouglas model, increased significantly from 0.525 in $1899-1903$ to 0.665 in $1899-1904$, 0.688 in 1899-1910, and 0.726 in 1899-1922 [17]. Factors such as trade policies, industrial policies, education, governance, culture, and geography are portrayed as technological progress.

\section{Data and methods}

\subsection{Data}

Data in this study come from the Indonesia Macroaggregate Quarterly Account. The study covered the period from the first quarter in 1970 to the fourth quarter in 2015. Therefore, there are 184 time-series observation in the study. The dependent variable is the gross domestic product (GDP) at current prices. The independent variables are investment (private and government expenditure) and population. Population consists of the whole population and employment opportunity.

To examine and study the share population to economic growth in Indonesia, the analysis is done for two time periods. The first period is the first 92 quarters (1970-1992), while the second period is the last 92 quarters (1993-2015).

\subsection{Methods}

The theory of economic growth states that economic growth is influenced by physical and human capital [18-21]. Physical capital includes investment and capital, while human capital can be people and employment opportunity. Therefore, in this study, the CobbDouglas $(\mathrm{CD})$ function was employed. The $\mathrm{CD}$ production function is a special functional form from the production function that is generally used to express technological 
relationship between two or more inputs. In general, the used inputs are capital and labor (population) and output that can be produced using that input. Sometimes constraints are imposed, such as the production function is constant returns to scale. Cobb-Douglas function was developed and tested statistically using empirical data by Charles Cobb and Paul Douglas in 1927-1947.

Model in this study employed nonlinear regression method that is generalized CobbDouglass (GDC) model, using time $t$ as input variable. Place the figure as close as possible after the point where it is first referenced in the text. If there is a large number of figures and tables it might be necessary to place some before their text citation.

\subsubsection{Model equation}

This study fits CD model in two parts. In the first part, CD model for Indonesia as a whole was examined from 1970 to 2015. The GDP used is GDP at current prices.

The Cobb-Douglas model in this part can be written as the following equation.

$$
Y=A K^{\alpha} L^{\beta}
$$

$Y=\mathrm{GDP}, K=$ capital and $L=$ manpower/population, $\alpha=$ capital share, and $\beta=$ population/employment share. $A$ is an exogenous productivity parameter. $\alpha$ and $\beta$ is, respectively, the share of capital and population in Cobb Douglass growth model. Endogenous growth theory named $A$ as "knowledge" or "effectiveness of labor" $[18,20$, 22].

To examine the demographic dividend using the population as a whole, model fitting for the following $\mathrm{CD}$ function model was carried out. The Cobb-Douglas model with dummy variable is as follows.

$$
Y=A_{1} I N V^{c(12)} P O P^{c(13)} D V 1+A_{2} I N V^{c(22)} P O P^{c(23)} D V 2
$$

$Y=\mathrm{GDP}, I N V=$ investment,$P O P=$ population, $A_{1}=$ technological progress in the first period, $c(12)=$ share of investment in the first period, $c(13)=$ share of population in the first period, $A_{2}=$ technological progress in the second period, $c(22)=$ share of investment in the second period, $c(23)=$ share of population in the second period, $D V 1$ and $D V 2$ are two dummy variables for time periods, that is $t \leq 92$ (1970-1992) and $t>92$ (1993-2015). Agung named this function as generalized Cobb-Douglas (GDC) model [23, 24].

To examine the demographic dividend through the employment opportunity, model fitting for the following CD function model was carried out. The model is as follows.

$$
Y=A_{1} I N V^{d(12)} P O P^{d(13)} D V 1+A_{2} I N V^{d(22)} P O P^{d(23)} D V 2
$$

$Y=$ GDP, $I N V=$ investment, $E M P=$ employment opportunity, $A_{1}=$ technological progress in the first period, $d(12)=$ share of investment in the first period, $d(13)=$ share of employment opportunity in the first period, $A_{2}=$ technological progress in the second period, $d(22)=$ share of investment in the second period, $d(23)=$ share of employment opportunity in the second period, $D V 1$ and $D V 2$ are two dummy variables for time periods, that is $t \leq 92$ (1970-1992) and $t>92$ (1993-2015). Agung also named this function as generalized Cobb-Douglas (GDC) model [23, 24].

In this study, the demographic dividend is defined as the increase in the share of population to the economy [25]. If this share increases by time, then it will be the magnitude of the demographic dividend reaped in Indonesia. 


\section{Results and discussion}

In Table 1, summary statistics of variables in the model are presented. These include the number of observations (Obs), mean, median, maximum, minimum, and standard deviation (Std.Dev.). It can be seen that the GDP of Indonesia increased from US\$808.9 million in Quarter 1 in 1970 to US\$2,205,996 million in Quarter 4 in 2015. Meanwhile, in the same period, the investment rose from US\$110.2 million to US\$ 755,392.6, the population multiplied more than twice from 115.9 million to 257.6 million people, and the employment grew from 20 million to more than 166 million.

Table 1. Summary Statistics of Variables in the Model.

\begin{tabular}{|l|c|c|c|c|c|c|}
\hline \multicolumn{1}{|c|}{ Variable } & Observations & Mean & Median & Minimum & Maximum & Std.Dev. \\
\hline $\begin{array}{l}\text { GDP (current } \\
\text { million US\$) }\end{array}$ & 184 & $425,144.3$ & $75,549.5$ & 808.9 & $2,205,996.0$ & $659,186.9$ \\
\hline $\begin{array}{l}\text { Investment } \\
\text { (current } \\
\text { million US\$) }\end{array}$ & 184 & $131,096.2$ & $20,530.0$ & 110.2 & $755,392.6$ & $221,905.7$ \\
\hline $\begin{array}{l}\text { Population } \\
(000)\end{array}$ & 184 & $184,652.7$ & $186,429.6$ & $115,929.7$ & $257,563.8$ & $40,231.5$ \\
\hline $\begin{array}{l}\text { Employment } \\
(000)\end{array}$ & 184 & $76,801.0$ & $78,603.7$ & $20,019.4$ & $166,258.6$ & $31,510.0$ \\
\hline
\end{tabular}

Source: Indonesia National Account in 1970-2015 (own calculation).

\subsection{Cobb-Douglas model}

The theory of Cobb-Douglas model in this part was done using constant-return-to scale (CRS) restriction, where the share of investment plus the share of population (whole population and employment) are restricted to be equal with one.

\subsubsection{Using the current price GDP and population}

It can be seen from Table 2 that during 1970-2015, the technological progress in Indonesia was 3.627 , the share of investment was $0.788(78.8 \%)$, and the share of whole population was $0.212(21.2 \%)$ to the economy (current price GDP) of Indonesia.

Table 2. Variable, Parameter Estimate, Standard Error, $t$-Statistic, and Probability for Cobb-Douglas Model between Investment and Population and Current Price GDP: Indonesia 1970-2015.

\begin{tabular}{|l|c|c|c|c|}
\hline \multicolumn{1}{|c|}{ Variable } & $\begin{array}{c}\text { Parameter } \\
\text { Estimate }\end{array}$ & $\begin{array}{c}\text { Standard } \\
\text { Error }\end{array}$ & $\boldsymbol{t}$-Statistic & Probability \\
\hline $\begin{array}{l}\text { Technological } \\
\text { progress }(A)\end{array}$ & 3.626768 & 0.029674 & 122.2185 & 0.0000 \\
\hline $\begin{array}{l}\text { Share of } \\
\text { investment }(\alpha)\end{array}$ & 0.787558 & 0.008826 & 89.23388 & 0.0000 \\
\hline $\begin{array}{l}\text { Share of } \\
\text { population }(\beta)\end{array}$ & 0.212442 & 89.23388 & 89.23388 & 0.0000 \\
\hline
\end{tabular}

Source: Indonesia National Account in 1970-2015 (own calculation).

\subsubsection{Using the current price GDP and employment opportunity}

It can be seen from Table 3 that technological progress in Indonesia was 4.273, during 1970-2015, the share of investment was 0.769 (76.9\%), and the share of employment opportunity was $0.231(23.1 \%)$ to the economy (current price GDP) of Indonesia. 
Table 3. Variable, Parameter Estimate, Standard Error, $t$-Statistic, and Probability for Cobb-Douglas Model between Investment and Employment and Current Price GDP: Indonesia 1970-2015.

\begin{tabular}{|l|c|c|c|c|}
\hline \multicolumn{1}{|c|}{ Variable } & $\begin{array}{c}\text { Parameter } \\
\text { Estimate }\end{array}$ & $\begin{array}{c}\text { Standard } \\
\text { Error }\end{array}$ & t-Statistic & Probability \\
\hline Technological progress $(A)$ & 4.273472 & 0.081185 & 52.63860 & 0.0000 \\
\hline Share of investment $(\alpha)$ & 0.769137 & 0.012617 & 60.96112 & 0.0000 \\
\hline Share of employment $(\beta)$ & 0.230863 & 0.012617 & 60.96112 & 0.0000 \\
\hline
\end{tabular}

Source: Indonesia National Account in 1970-2010 (own calculation).

\subsection{Generalized Cobb-Douglas model}

This model was employed to measure the demographic dividend. In this model, the time is divided into two periods: first 92 quarters (1970-1992) and last 92 quarters (1993-2015). The results of model fitting are as follows (Table 4).

Table 4. Variable, Parameter Estimate, Standard Error, $t$-Statistic, and Probability for Generalized Cobb-Douglas Model between Investment and Population and Current Price GDP: Indonesia 19702015.

\begin{tabular}{|l|c|c|c|c|}
\hline \multicolumn{1}{|c|}{ Variable } & $\begin{array}{c}\text { Parameter } \\
\text { Estimate }\end{array}$ & Standard Error & $\boldsymbol{t}$-Statistic & Probability \\
\hline$A_{1}$ & 2.138768 & 1.691559 & 1.264377 & 0.2077 \\
\hline$c(12)$ & 0.793583 & 0.293658 & 2.702406 & 0.0075 \\
\hline$c(13)$ & 0.206417 & 0.293658 & 2.702406 & 0.0075 \\
\hline$A_{2}$ & 3.667257 & 0.029127 & 125.9074 & 0.0000 \\
\hline$c(22)$ & 0.774709 & 0.008637 & 89.69956 & 0.0000 \\
\hline$c(23)$ & 0.225291 & 0.008637 & 89.69956 & 0.0000 \\
\hline
\end{tabular}

Source: Indonesia National Account in 1970-2015 (own calculation).

It can be seen from Table 4 that during 1970-1992 technological progress in Indonesia was 2.139 , the share of investment $(c(12))$ was 0.794 (79.4\%), and the share of population $(c(13))$ was $0.206(20.6 \%)$ to the economy (current price GDP) of Indonesia. Meanwhile, during 1993-2015, technological progress in Indonesia was 3.667, the share of investment $(c(22))$ was $0.775(77.5 \%)$ and the share of population $(c(23))$ was $0.225(22.5 \%)$ to the economy (current price GDP) of Indonesia. It means that there was an improvement in technological progress in Indonesia during 1970-2015, from 2.139 in 1970-1992 to 3.667 in 1993-2015.

The demographic dividend through the whole population is the difference of the share of population between $1970-1992$ and 1993-2015. It is $c(23)-c(13)=0.225291-$ $0.206417=0.018874$ or $1.8874 \%$. Therefore, the demographic dividend through the whole population in Indonesia during 1970-2015 is $1.8874 \%$. This result is consistent with finding by Mason (2005) and Maliki (2014).

In Table 5 the results of model fitting using the current price GDP with investment and employment opportunity as the independent variables. It can be seen from Table 5 that, during 1970-1992, technological progress in Indonesia was 2.451, the share of investment was $(d(12)) 0.766(76.6 \%)$, and the share of employment opportunity $(d(13))$ was 0.234 (23.4\%) to the economy (current price GDP) of Indonesia. Meanwhile, during 1993-2015, technological progress in Indonesia was 4.387 , the share of investment $(d(22))$ was 0.752 
(75.2\%) and the share of employment opportunity $(d(23))$ was $0.248(24.8 \%)$ to the economy (current price GDP) of Indonesia. It means, based on this model, that there was an improvement in technological progress in Indonesia during 1970-2015, from 2.451 in 1970-1992 to 4.387 in 1993-2015.

Table 5. Variable, Parameter Estimate, Standard Error, $t$-Statistic, and Probability for Generalized Cobb-Douglas Model between Investment and Employment Opportunity and Current Price GDP: Indonesia 1970-2015.

\begin{tabular}{|l|c|c|c|c|}
\hline \multicolumn{1}{|c|}{ Variable } & $\begin{array}{c}\text { Parameter } \\
\text { Estimate }\end{array}$ & Standard Error & $\boldsymbol{t}$-Statistic & Probability \\
\hline$A_{1}$ & 2.450927 & 1.775801 & 1.380181 & 0.1692 \\
\hline$d(12)$ & 0.766301 & 0.398819 & 1.921427 & 0.0563 \\
\hline$d(13)$ & 0.233669 & 0.398819 & 1.921427 & 0.0563 \\
\hline$A_{2}$ & 4.386645 & 0.083428 & 52.57982 & 0.0000 \\
\hline$d(22)$ & 0.751774 & 0.012657 & 59.39543 & 0.0000 \\
\hline$d(23)$ & 0.248226 & 0.012657 & 59.39543 & 0.0000 \\
\hline
\end{tabular}

Source: Indonesia National Account in 2007-2015 (own calculation).

The demographic dividend through the employment opportunity is the difference of the share of employment opportunity between 1970-1992 and 1993-2015. It is $d(23)-d(13)=$ $0.248226-0.233669=0.014557$ or $1.4557 \%$. Therefore, the demographic dividend through the employment opportunity in Indonesia during 1970-2015 is $1.4557 \%$.

\section{Conclusions and policy implications}

The results of the study show that in Indonesia, during the period of 1970-2015, the share of population was $21.2 \%$ and the share of employment opportunity was $23.1 \%$. The demographic dividend using the population as a whole was $1.8874 \%$ and the demographic dividend through the employment opportunity in Indonesia during 1970-2015 was $1.4557 \%$. In addition, the new measure of demographic dividend proposed in this study can be used as an alternative measure of demographic dividend in Indonesia.

The results of this study support that population dynamics in Indonesia has contributed positively to the economic growth in the country. This implies that the window of opportunity should be capitalized in order to reap higher demographic dividend through the improvement of human resources development, in particular health, education, and productive employment opportunity. In addition, the capacity of national and sub-national to formulate policies to capitalize window of opportunity to reap the demographic dividend should be enhanced.

\section{References}

1. Indonesia Economics Report 2017 (2017)

2. Growth and Distribution of Population of Indonesia Results of the 2010 Population Census (2011)

3. T.H. Hull, People, Population, and Policy in Indonesia (2005)

4. Fertility of Population of Indonesia Results of the 2010 Population Census (2011) 
5. Age and Gender of Population of Indonesia Results of the 2010 Population Census (2011)

6. Indonesia's 2010-2035 Population Projection (2013)

7. S.A. Ahmed, M. Cruz, B. Quillin, P. Schellekens, Policy Research Working Paper 7893 (2016)

8. W. Rajagukguk, O.B. Samosir, Demographic Dynamics in Indonesia in 1950-2100 (2015)

9. O.B. Samosir, The Literacy of Population Dynamics and the Results of Indonesia's Population Projection in 2010-2035 (The Ministry of National Development Planning/National Development Planning Agency of the Republic of Indonesia, 2015)

10. H. Mai, H. Van, D. Ushakov, Inter. J. of Recent Technology and Engineering 8(2S11) (2019)

11. J. Simon, The Ultimate Resource 2 (1974)

12. D. Romer, J. Econ. Perspect. 8, 3-22 (1994)

13. C.I. Jones, Population and Ideas: A Theory of Endogenous Growth (2001)

14. W. Rajagukguk, Actual Problems of Economics 9, 42-48 (2017)

15. A. Mason, Proceedings of the United Nations Expert Group Meeting on Social and Economic Implications of Changing Population Age Structures, 81-101 (2005)

16. Maliki, Policy in Focus: National Transfer Accounts and Generational Flows. 30, 2931 (2014)

17. J. Felipe, F.G. Adams, East. Econ J. 31, 427-44 (2005)

18. R.J. Barro, X. Sala-i-Martin, Economic Growth (1995)

19. A. Young, Q. J. Econ. 110, 641-680 (1995)

20. P. Aghion, P. Howitt, Endogenous Growth Theory, 329-357 (1998)

21. D. Ray, Development Economics (1998)

22. D. Romer, Advanced Macroeconomics (1996)

23. I.N. Agung, Some Nonparametrics Procedures for General Right Censored Data (1981)

24. I.N. Agung, Time Series Data Analysis Using EViews, 473-491 (2009)

25. A. Tran, N. Minh, D. Ushakov, Inter. J.of Recent Technology and Engineering 8(2S11) (2019) 